\title{
Bifidobacterium longum
}

National Cancer Institute

\section{Source}

National Cancer Institute. Bifidobacterium longum. NCI Thesaurus. Code C86199.

A species of anaerobic, Gram-positive, rod shaped bacteria assigned to the phylum Actinobacteria. This species is nonmotile, nonsporeforming, catalase and indole negative and ferments arabinose, xylose, ribose, lactose and melezitose. B. longum is nonpathogenic, and it helps maintain a healthy digestive system. 